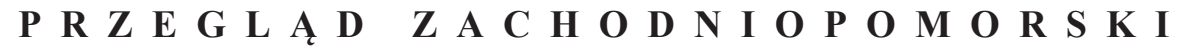 ROCZNIK XXXV (LXIV) ROK 2020 ZESZYT 1
}

\section{$\begin{array}{llllllll}\mathbf{A} & \mathbf{R} & \mathbf{T} & \mathbf{Y} & \mathbf{K} & \mathbf{U} & \mathbf{L} & \mathbf{Y}\end{array}$}

\author{
Grzegorz Ciechanowski \\ ORCID: 0000-0001-9758-947X \\ Uniwersytet Szczeciński \\ e-mail: gc57@op.pl
}

\section{KAWALERYJSKIE BARWY I TRADYCJE WSPÓŁCZESNYCH JEDNOSTEK WOJSKOWYCH GARNIZONU STARGARD}

Słowa kluczowe: Wojsko Polskie, tradycje wojskowe, kawaleria, falerystyka, Pomorze Zachodnie, Stargard

Keywords: Polish Army, military traditions, cavalry, phaleristics, Western Pomerania, Stargard

\section{Prawne podstawy przemian w Wojsku Polskim po 1990 roku}

Po 1989 roku w Siłach Zbrojnych RP dokonano przemian na wielu polach, wśród nich zaistniał silny trend dążący do przywrócenia wojsku wielowiekowych tradycji. Rozwijał się on na różnych poziomach, od poszczególnych jednostek po Ministerstwo Obrony Narodowej. W marcu 1990 roku szef resortu powołał zespół ekspertów w celu opracowania zasad dziedziczenia tradycji, barw i symboli sił zbrojnych. W jego składzie znalazło się około trzydziestu historyków, m.in. prof. Aleksander Gieysztor, prof. Andrzej Nadolski, prof. Józef Szymański, prof. Tadeusz Rawski ${ }^{1}$. Za podstawę prac eksperci przyjęli uregulowania prawne z 1927

${ }^{1}$ Dariusz Radziwiłłowicz, Tradycje i symbole współczesnych jednostek WP na Warmii i Mazurach (maszynopis niepublikowany), 6. 
roku (wraz z nowelizacją z 1938 r.) ${ }^{2}$, odwoływali się także do symboliki wojskowej okresu II Rzeczypospolitej. Opierano się przy tym na wiedzy z zakresu heraldyki, weksylologii i falerystyki ${ }^{3}$. Kluczowym rezultatem pracy zespołu była treść ustawy z 9 lutego 1993 roku O znakach Sit Zbrojnych Rzeczypospolitej Polskiej, ale pierwszym dokumentem wykonawczym w tej dziedzinie stał się rozkaz ministra Obrony Narodowej (ON) Nr 1/MON z 2 stycznia 1991 roku w sprawie dziedziczenia i kultywowania tradycji oręża polskiego. Dokument miał przełomowe znaczenie, bowiem w okresie PRL, a właściwie formalnie do ukazania się tego rozkazu, dziedzictwo jednostek WP ograniczało się jedynie do spuścizny jednostek 1. i 2. Armii Wojska Polskiego a także partyzanckich formacji Gwardii i Armii Ludowej. Teraz odwoływano się do tysiącletnich tradycji oręża, poczynając od czasów piastowskich. Kilka lat później w życie weszła decyzja $\mathrm{Nr} 229$ / MON z 11 sierpnia 2004 roku, w której przekazano możliwość nadawania tradycji i imion patronów pododdziałom wojskowym, a nie jak dotychczas jedynie oddziałom ${ }^{4}$.

Zgodnie z rozkazem inicjatywę przyjęcia nazwy wyróżniającej, związanej z dziedziczeniem tradycji oraz nadania imienia patrona, przyznano żołnierzom jednostki wojskowej. Przyjęcie tradycji określonych formacji wymagało uzyskania przez starającego się zgody władz organizacji kombatanckich, związków broni, kół dywizyjnych, pułkowych, a także najbliższej rodziny na używanie nazwiska patrona w nazwie jednostki ${ }^{5}$. Nierzadko o doborze patronów decydował Departament Wychowania MON.

${ }^{2}$ W 1927 roku, zgodnie z dekretem prezydenta państwa, zmieniony został rysunek godła państwowego, a minister spraw wojskowych wprowadził nowe godła na płaty sztandarów wojskowych.

${ }^{3}$ Heraldyka - jedna z nauk pomocniczych historii, która zajmuje się badaniem rozwoju i znaczenia oraz zasadami kształtowania się herbów. Weksylologia i falerystyka to dyscypliny pomocnicze historii, które wyodrębniły się z heraldyki, zachowując wspólne z nią metody badawcze. Weksylologia zajmuje się chorągwiami jako rzeczywistymi i symbolicznymi znakami wojskowymi, państwowymi, terytorialnymi, organizacji i grup społecznych a także wyznaniowych. Falerystyka - orderami, odznaczeniami i innymi odznakami oraz znakami honorowymi. Zob. Alfred Znamierowski, Heraldyka i weksylologia (Warszawa: Arkady, 2017), 12-24; Krzysztof Filipow, „Rozwój badań nad falerystyką w Polsce. Stan i perspektywy”, Kwartalnik Historii Nauki i Techniki 37 (1985), 2: 357-370.

${ }^{4}$ Kultywowanie tradycji oręża polskiego w Wojsku Polskim, dostęp 27.12.2018, https://tradycje. wp.mil.pl.

5 Po 1990 roku, wzorem armii czasów PRL, jednostkom nadawano patronów. Zrezygnowano z sięgającej czasów I Rzeczypospolitej tradycji przyznawania stopnia bądź funkcji szefa jednostki (pułku). W armii koronnej i Wielkiego Księstwa Litewskiego okresu I Rzeczypospolitej funkcjonował oficjalny stopień szefa pułku (powyżej pułkownika). Stopnia tego nie przywrócono 
Na początku lat 90. XX wieku na Pomorzu Zachodnim stacjonowały następujące związki taktyczne wojsk lądowych: szczecinecka 2. Pomorska Dywizja Zmechanizowana (DZ), koszalińska 8. Bałtycka Dywizja Obrony Wybrzeża (DOW), 12. Szczecińska DZ oraz słupskie i lęborskie jednostki 7. Łużyckiej Brygady Obrony Wybrzeża (BOW) ${ }^{6}$. Wchodzące w ich skład formacje szukały swoich protoplastów. Jednostki zmechanizowane wybierały ich z grona oddziałów piechoty najczęściej o tym samym numerze, natomiast artylerzyści, łącznościowcy, saperzy, wojskowi medycy czy żołnierze innych jednostek o określonym profilu mieli swoich poprzedników reprezentujących określony rodzaj służby. Był tylko jeden wyjątek - w Polsce od 1946 roku nie było jednostek kawalerii, trzeba więc było wytypować formacje, którym można przekazać wspaniałe tradycje tego rodzaju broni. W związku z koncepcją przeformowania pułków zmechanizowanych w brygady pancerne i zmechanizowane, Zespół ds. Dziedziczenia Tradycji Oręża Polskiego w MON przyjął założenie, że tradycje kawaleryjskie będą dziedziczyły jednostki pancerne (kawalerii pancernej) oraz dywizyjne bataliony rozpoznawcze.

\section{Stargardzkie dziedzictwo ułanów jazłowieckich}

Na początku lat 90. XX wieku szczególne miejsce na wojskowej mapie Pomorza Zachodniego zajmował stargardzki garnizon, tu bowiem stacjonowały liczne jednostki wchodzące w skład dwóch różnych związków taktycznych. W tej grupie był m.in. 2. Batalion Rozpoznawczy 2. Warszawskiej DZ i 9. Pułk Zmechanizowany 12. Szczecińskiej DZ. W 1995 roku na bazie tego ostatniego utworzono 6. Brygadę Pancerną ${ }^{7}$ którą rok później przemianowano w 6. Brygadę Kawalerii Pancernej. Niezwłocznie podjęto działania mające na celu nadanie nowotworzonej formacji tradycji Podolskiej Brygady Kawalerii, w której skład wchodził m.in. jeden z najsławniejszych - 14. Pułk Ułanów Jazłowieckich stacjonujący w okresie II RP we Lwowie. Przeszkodą na drodze do osiągnięcia tego celu był brak

ani w armii Księstwa Warszawskiego, ani Królestwa Polskiego (1815-1831), ale w siłach zbrojnych II RP funkcjonowało stanowisko (ale nie stopień) szefa pułku. Zob. Aleksander Smoliński, „W sprawie przywracania tradycji we współczesnym Wojsku Polskim (sztandary, nazwy formacji, "mundur)", w: IV Ogólnopolskie Forum Historyków Wojskowych. Koszalin 16 XII 1998, red. Bogusław Polak (Koszalin: Politechnika Koszalińska, 1999), 57.

${ }^{6}$ Do 2001 roku w regionie istniały jeszcze dwa wyspecjalizowane związki taktyczne wojsk lądowych - 5. Mazurska Brygada Saperów im. gen. Ignacego Prądzyńskiego w Szczecinie Podjuchach i 2. Brygada Łączności w Wałczu.

7 6. Brygadę Pancerną sformowano decyzją Szefa Sztabu Generalnego WP Nr 086/org. z dn. 19.12.1994 r. 
kontaktu z weteranami kawalerii i artylerii konnej. Pomógł tu przypadek, w tym czasie praktykę dowódczą w kompanii rozpoznawczej tworzącej się brygady odbywał podchorąży Juliusz S. Tym (dziś pułkownik dr hab., profesor Akademii Sztuki Wojennej, dyrektor Instytutu Historii Wojskowości i Stużb Specjalnych tejże uczelni), który z racji swych kawaleryjsko-jeździeckich zainteresowań od lat związany był z tym środowiskiem i umożliwił pierwsze kontakty z gronem ułanów jazłowieckich w kraju, przede wszystkim mjr. w st. spocz. Eugeniuszem Iwanowskim. Opracował też projekt listów intencyjnych do trzech londyńskich kół pułków ułanów oraz Zrzeszenia Artylerii Konnej. Pomocy brygadzie udzielił też por. Marek Dragan (dziś pułkownik i dowódca Centralnej Grupy Działań Psychologicznych), którego kawaleryjsko-jeździecka aktywność od lat dotyczyła przede wszystkim 14. Pułku Ułanów Jazłowieckich ${ }^{8}$. Obaj weszli w skład Komisji ds. Tradycji, powołanej 12 kwietnia 1995 roku rozkazem dowódcy brygady. W staraniach o przejęcie ułańskiej tradycji bardzo dużego wsparcia udzieliła Rodzina Jazłowiecka w Polsce9. W tym czasie, co miało duże znaczenie, w 6. BKPanc obsadzono już 80 proc. etatu (ok. 2200 żołnierzy).

Powołana przez dowódcę brygady Komisja ds. Tradycji przygotowała wniosek do ministra Obrony Narodowej o nadanie tradycji, wyznaczenie patrona oraz daty święta jednostki. Jako patrona rekomendowano gen. bryg. Konstantego Plisowskiego, organizatora i pierwszego dowódcę 14. Pułku Ułanów Jazłowieckich, jako datę święta brygady wskazano 31 sierpnia - dzień zwycięskiej bitwy VI Brygady Jazdy i całej 1. Dywizji Jazdy z jednostkami sowieckiej I Armii Konnej pod Komarowem, stoczonej w 1920 roku.

Zgodnie z obowiązującą procedurą, możliwość skierowania powyższego wniosku do szefa resortu zależała od akceptacji tego projektu przez weteranów, z którymi jak wspomniano, nawiązano już kontakt. Reakcja Koła Pułkowego 14. Pułku Ułanów Jazłowieckich była niezwłoczna, podczas pobytu w Polsce (15 września-2 października 1995 roku) prezes koła mjr w st. spocz. Jerzy T. Nawrocki wręczył dowódcy 6. Brygady Kawalerii Pancernej protokół przekazania barw i tradycji 14. Pułku Ułanów Jazłowieckich 1. batalionowi czołgów

\footnotetext{
${ }^{8}$ Juliusz S. Tym, red., Dzieje ułanów jazłowieckich (Warszawa: IPN, 2019), 491.

9 Rodzina 14 Pułku Ułanów Jazłowieckich (w skrócie Rodzina Jazłowiecka) to jeden z największych związków rodzinno-kombatanckich, stowarzyszenie zarejestrowane sądownie, działające od 1995 roku z upoważnienia Koła Pułkowego w Londynie. To kontynuatorka Kół Pułkowych we Wrocławiu i Warszawie, zrzeszająca weteranów - kombatantów 14. Pułku, ich rodziny, historyków kawalerii oraz wyjątkowo inne osoby zasłużone dla jego historii i tradycji. Zob. Rodzina 14 Pułku Ułanów Jazłowieckich, dostęp 12.10.2019, http://www.ulanijazlowieccy.pl.
} 
sporządzony na mocy uchwały walnego zebrania koła, jednakże tę zgodę uzależniono od spełnienia następujących warunków:

- odzwierciedlenia historii i tradycji pułkowych w sali tradycji batalionu,

- przodowania 1. bcz w wyszkoleniu wojskowym brygady,

- propagowania związków ułanów jazłowieckich z klasztorem i zgromadzeniem ss. niepokalanek i Matką Boską Jazłowiecką poprzez włączenie Modlitwy ułana jazłowieckiego do ceremonii batalionowych (m.in. podczas święta pułkowego, przysięgi wojskowej, mszy św.),

- corocznego pielgrzymowania reprezentacji batalionu do Sanktuarium Matki Boskiej Jazłowieckiej w Szymanowie,

- wprowadzenia w miarę możliwości przedwojennych, kawaleryjskich nazw stopni wojskowych ${ }^{10}$.

Koła pułkowe w kolejnych miesiącach wyraziły zgodę na przekazanie tradycji, co stało się podstawą do wystąpienia przez brygadę z wnioskiem do ministra ON, który 20 marca 1996 roku decyzją nr 38/MON nakazał 6. Brygadzie Kawalerii Pancernej ze Stargardu Szczecińskiego przyjąć i z honorem kontynuować tradycje VI Brygady Jazdy (1920-1924), 6. Samodzielnej Brygady Kawalerii (1924-1937), Podolskiej Brygady Kawalerii (1937-1939) oraz podległych oddziałów, przyjąć jako patrona gen. bryg. Konstantego Plisowskiego, a święto obchodzić 31 sierpnia, w rocznicę boju pod Komarowem.

Tradycje jednostek Podolskiej BK przejęły, poprzez nadanie imienia, pododdziały 6. BK Panc:

- 1. batalion czołgów im. 14. Pułku Ułanów Jazłowieckich,

- 2. batalion czołgów im. 6. Pułku Ułanów Kaniowskich,

- 3. batalion czołgów im. 9. Pułk Ułanów Małopolskich,

- batalion zmechanizowany im. 9. Zaodrzańskiego Pułku Piechoty,

- dywizjon artylerii samobieżnej im. 6. Dywizjonu Artylerii Konnej,

- dywizjon przeciwlotniczy im. 86. Baterii Przeciwlotniczej ${ }^{11}$.

${ }^{10}$ Wśród przedstawionych warunków przekazanych przez weteranów znajdowało się też zobowiązanie dowództwa batalionu do udzielania pomocy 14. Drużynie Harcerskiej im. 14. Pułku Ułanów Jazłowieckich z Sochaczewa (na podstawie porozumienia między ministrem ON i naczelnikiem Związku Harcerstwa Polskiego z grudnia 1993 r.). Więcej na temat procesu przekazywania tradycji zob. Tym, Dzieje ułanów, 492.

${ }^{11}$ Rozkaz Dowódcy 6. Brygady Kawalerii Pancernej nr 103 z dn. 30.08 .1996 w sprawie przekazania tradycji dla pododdziałów 6. Brygady Kawalerii Pancerne; Kronika 1. Batalionu Czołgów 6. Brygady Kawalerii Pancernej, Sala Tradycji 12. Brygady Zmechanizowanej w Stargardzie, 8. Batalionowi zmechanizowanemu 6. BKPanc przypisano nieułańskie tradycje 9. Zaodrzańskiego Pułku Piechoty, zasłużonej w bojach jednostki wchodzącej w skład 3. Pomorskiej DP 1. Armii 
Uroczystości dziedziczenia historii i barw odbyły się 30 i 31 sierpnia 1996 roku, kulminacja nastąpiła drugiego dnia, kiedy 6. Brygadzie Kawalerii Pancernej im. gen. bryg. Konstantego Plisowskiego wręczono sztandar. Na uroczystość do Stargardu Szczecińskiego przybyli weterani z całego świata, w tym córka patrona brygady Teresa Plisowska-Rosen, która wcześniej wyraziła zgodę na taki sposób upamiętnienia swojego ojca ${ }^{12}$.

Warto kilka zdań poświęcić sławnemu 14. Pułkowi Ułanów Jazłowieckich, który po przemarszu z Odessy przez Rumunię dotarł do niepodległej Polski, gdzie pod koniec czerwca 1919 roku rozpoczął działania zbrojne w wojnie polsko-ukraińskiej w Małopolsce Wschodniej. Pułk dowodzony przez mjra K. Plisowskiego, podczas walk toczonych 11-13 lipca pod Jazłowcem i Chmielową, wsławił się brawurową szarżą, w rezultacie czego nie dopuścił przeciwnika do klasztoru Sióstr Niepokalanek w Jazłowcu, a NMP Jazłowiecka została patronką jednostki, która przyjęła swą nazwę od tego właśnie miejsca ${ }^{13}$. Wiosną 1920 roku wziął udział w wyprawie kijowskiej, a latem tego roku pułk, wraz z całą armią, przeszedł do działań ofensywnych, 31 sierpnia bił się, jak wspomniano, pod Komarowem, a następnie 8-12 października uczestniczył w zagonie na Korosteń ${ }^{14}$. Za walki w latach 1918-1920 pułk został odznaczony przez marszałka Józefa Piłsudskiego Orderem Virtuti Militari V klasy.

W okresie międzywojennym 14. puł Jazłowieckich stacjonował we Lwowie, skąd w sierpniu 1939 roku w strukturach Podolskiej BK, przydzielonej do Armii Poznań, ruszył do Wielkopolski. Do historii oręża polskiego przeszła szarża pod Wólką Węglową przeprowadzona przez pułk 19 września 1939 roku, którą to ułani jazłowieccy otworzyli drogę do Warszawy jednostkom Armii Poznań. W stolicy walczyli aż do kapitulacji miasta.

WP. Pułk w sierpniu 1944 roku prowadził walki na przyczółku warecko-magnuszewskim, później niósł pomoc powstańcom warszawskim na przyczółku czerniakowskim. Na Wale Pomorskim walczył w rejonie Nadarzyc, w Kołobrzegu w marcu 1945 roku zdobył silnie umocniony rejon gazowni. W kwietniu forsował Odrę i walczył na terenie Brandenburgii. W 1946 roku za wykazane bohaterstwo został odznaczony Krzyżem Orderu „Virtuti Militari” V kl i otrzymał miano „Zaodrzańskiego".

${ }^{12}$ Kronika 1. Batalionu Czołgów. Szczegółowy opis ceremonii przekazania tradycji został opisany w: Tym, Dzieje ułanów, 494-495.

13 Stanowiło to początek utrzymywanych przez cały okres międzywojenny więzi 14. puł Jazłowieckich z klasztorem. Po przekazaniu tradycji zarówno żołnierze 1. bcz 6. BKPanc, jak i 2. bpzmot 12. BZ odwiedzali klasztor Sióstr Niepokalanek przeniesiony po wojnie do Szymanowa.

${ }^{14}$ Wcześniej, w końcu kwietnia 1919 r., ułani jazłowieccy uczestniczyli w zagonie na Koziatyn. 
Nieprzypadkowo zatem odznaka 6. BKPanc nawiązywała właśnie do kształtu znaku 14. Pułku Ułanów Jazłowieckich zaprojektowanego w 1921 roku przez rtm. Jerzego Onoszkowicza-Jacynę i por. Waleriana Januszewskiego ${ }^{15}$. W lewym górnym polu wiązki promieni otaczających biały krzyż maltański, a interpretowanej jak słońce Podola ${ }^{16}$, autorzy projektu umieścili inicjały „UJ”, w prawym dolnym liczbę „1918”, na środku zaś Srebrny Krzyż Orderu Virtuti Militari, którym jak wspomniano, pułk został odznaczony po wojnie polsko-bolszewickiej ${ }^{17}$.

Należy dodać że wiele elementów barwy polskiej kawalerii okresu II RP, szczególnie tych wiążących się z tak zwaną ułańską fantazją, w tym słynne żurawiejki, miało swój pierwowzór w rosyjskiej tradycji wojskowej. Przykładem może być choćby przytoczony rodowód odznaki. Ta zadziwiająca parabola wynikała głównie z faktu, iż od 1831 roku nie istniały własne, narodowe i regularne siły zbrojne. Epoka rozbiorów skutkowała powstaniem wielopokoleniowej luki W rozwoju polskiej tradycji wojskowej ${ }^{18}$, stąd, choć bogato czerpano z własnej symboliki, nierzadko sięgano do wzorców obcych armii. W opisanym przypadku było to tym łatwiejsze, że wielu oficerów 14. puł służyło wcześniej w carskiej kawalerii.

Warto dodać, że po klęsce wrześniowej wielu Ułanów Jazłowieckich przez Węgry i Rumunię przedostało się do Francji19. Dzięki staraniom oficerów pułku, w marcu 1940 roku w 10. Brygadzie Kawalerii Pancernej gen. bryg. Stanisława Maczka utworzono batalion im. Ułanów Jazłowieckich. Ten pododdział z bronią, drogą morską przedostał się do Wielkiej Brytanii. W formowanych tam Pol-

15 Analizując sylwetkę odznaki 14. puł, można postawić tezę, że twórców mógł zainspirować wzór odznaki Korpusu Paziów Jego Imperatorskiej Wysokości, najbardziej prestiżowej uczelni wojskowej w Imperium Rosyjskim. Porusza ten wątek m.in. Krzysztof Goździk, Znak Pułkowy 14 Pułku Ułanów Jazłowieckich, dostęp 1.02.2019, https://dobroni.pl.

16 Zdzisław Sawicki, Adam Wielechowski, Odznaki Wojska Polskiego 1918-1945. Katalog Zbioru Falerystycznego: Wojsko Polskie 1918-1939: Polskie Sity Zbrojne Na Zachodzie (Warszawa: Pantera Books, 2007), 187-188.

17 Krzysztof Filipow, Odznaki pamiatkowe Wojska Polskiego 1921-1939. Kawaleria (Warszawa: Feniks, 1992), 23-25; Henryk Wielecki, Rudolf Sieradzki, Wojsko Polskie 1921-1939: organizacja i odznaki kawalerii (Warszawa: Crear, 1992), 88-89.

18 Smoliński, „W sprawie”, 57; Krzysztof Mijakowski, red., 14. Pułk Ułanów Jazłowieckich. Wielka Ksiega Kawalerii Polskiej 1918-1939 (Warszawa: Edipresse Polska, 2012), 14-16.

19 Część ułanów, którzy stanowili nadwyżki mobilizacyjne 14. puł weszła w skład sformowanego 14 września 1939 roku Marszowego Pułku Podolskiej BK, który zgodnie z rozkazem przeszedł na teren Węgier, podobnie jak jazłowiacy z Ośrodka Zapasowego brygady. Zieloną granicę przekroczyła też pewna grupa oficerów pułku. Zob. Lesław Kukawski, Ułani Jazłowieccy. Barwa i broń 1918-1998 (Grajewo, 2001), 15. 
skich Siłach Zbrojnych 1. batalion strzelców 1. Brygady Strzelców otrzymał imię 14. Pułku Ułanów Jazłowieckich. Taki był początek starań o odtworzenie na Wyspach sławnej jednostki. Te działania, po odmowie gen. Władysława Sikorskiego co do przywrócenia tradycyjnej nazwy, zakończyły się połowicznym sukcesem i 17 sierpnia 1942 roku batalion przemianowano na 14. Pułk Kawalerii Pancernej (14. pkpanc). Dopiero 8 stycznia 1944 roku przyznano mu nazwę 14. Pułku Ułanów Jazłowieckich ${ }^{20}$. Kilka miesięcy po przekształceniu batalionu w pułk, ułan Teodor Hartglas zaprojektował odznakę pamiątkową jednostki, która została zatwierdzona pismem Gabinetu Naczelnego Wodza i Ministra Spraw Wojskowych 1 października 1942 roku $^{21}$. Miała ona kształt krzyża maltańskiego z lekko wypukłym obramowaniem, w odznakach oficerskich pokrytego białą emalią. Kokardę pod krzyżem stanowiło koło z sylwetkami przednich części czołgów, ukazanych z góry, które wiązały jego ramiona. W środku krzyża umieszczono sześciokąt, na którym umieszczone zostały inicjały „UJ”, oznajmiające kontynuowanie tradycji 14. Pułku Ułanów Jazłowieckich. Odznaka dla szeregowych była bez emalii, z oksydowanego metalu, a wymiary obydwu wersji wynosiły 50 x $50 \mathrm{~mm}$. Wykonywała je firma Firma Chisholm and Mackay z Edynburga ${ }^{22}$.

Odznaki 14. Pułku Ułanów Jazłowieckich 16. BKPanc według przedwojennego wzoru wybiła w srebrze londyńska firma Spink and Son. Znana jest również wersja odznaki, w której ramiona krzyża pokryte zostały białą emalią z czarno -granatowym tłem Orderu Virtuti Militari i pozłacanymi inicjałami oraz datą ${ }^{23}$. Co ciekawe, 6. Brygadzie Kawalerii Pancernej nie przekazano tradycji formacji Ułanów Jazłowieckich utworzonych we Francji i w Wielkiej Brytanii.

20 14. Pułk Ułanów Jazłowieckich wchodził wówczas w skład 16. Samodzielnej Brygady Pancernej, która nie wzięła udziału w walkach, pozostając w Wielkiej Brytanii. Żołnierze pułku kierowani byli, w celu uzupełnienia strat, do oddziałów 1. Dywizji Pancernej uczestniczącej w wyzwalaniu Francji, Holandii, kończącej swój szlak bojowy w Niemczech.

${ }^{21}$ Kukawski, Ułani Jazłowieccy.

22 Tamże; Jan Partyka, Odznaki i oznaki Polskich Sit Zbrojnych na Zachodzie 1939-1945 (wojska ladowe) (Rzeszów: Libri Ressovienses, 1997), 41.

${ }^{23}$ Partyka, Odznaki; Józef Dembiniok, Bernard Szczech, Andrzej Urbański, Oznaki i odznaki Polskich Sił Zbrojnych na Zachodzie. Część I, Wojsko Polskie we Francji I Korpus Polski w Wielkiej Brytanii (Warszawa: KAW, 1984), 154. 

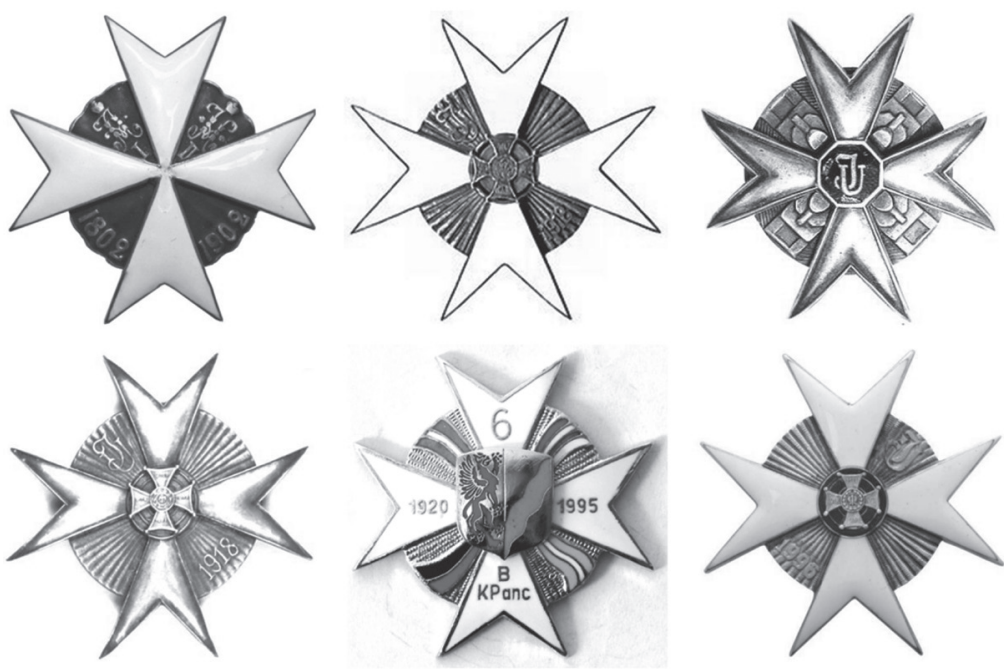

Rycina 1. Ewolucja kształtu odznaki: od góry, od lewej: odznaka Korpusu Paziów Jego Imperatorskiej Wysokości, oficerska 14.puł, 14. pkpanc, 14.puł (Spink and Son), 6. BKPanc, 2. bpzmot 12. BZ (opracowanie własne)

Wracając do Stargardu i wątku falerystycznego, komisja do spraw tradycji utworzona w 6. BKPanc opracowała regulamin odznaki pamiątkowej i 17 maja 1995 roku przedstawiła go do konsultacji oraz zatwierdzenia przez zebranie oficerskie, chorążych i podoficerów zawodowych. Regulamin został przesłany do ministra ON, który decyzją nr 38 z dnia 20 marca 1996 roku zatwierdził go. Opracowana przez mjr. Leszka Ziółkowskiego, przy udziale por. Marka Dragana i st. kpr. pchor. Juliusza S. Tyma odznaka o wymiarach 45 x $45 \mathrm{~mm}$ to krzyż kawalerski pokryty białą emalią. W jego centrum umieszczono tarczę z herbem Stargardu, na pionowych ramionach krzyża - cyfrę „6” (górne ramię) i inicjały „BKPanc” (dolne), na poziomych daty - „1920” (lewe) i „1995” (prawe). Pierwsza to rok powstania VI Brygady Jazdy i zwycięskiej bitwy pod Komarowem, druga symbolizuje utworzenie 6. Brygady Kawalerii Pancernej. Między ramionami krzyża na wiązkach promieni umieszczono cztery proporczyki jednostek Podolskiej Brygady Kawalerii: 6. Pułku Ułanów (puł), 9. puł, 14. puł i 6. Dywizjonu Artylerii Konnej (dak). Odznaki wykonała pracownia grawerska Elżbiety Graczyk z Poznania, a pierwsze egzemplarze wręczono 3 maja 1996 roku $^{24}$. Jak

${ }^{24}$ Zdzisław Sawicki, Adam Wielechowski, Odznaki Wojska Polskiego 1989-2002. Katalog zbioru falerystycznego (Warszawa: Bellona, 2003), 35. 
zaznacza Lesław Kukawski, autor książki poświęconej Ułanom Jazłowieckim, w projekcie odznaki nie uwzględniono ważnej tradycji funkcjonującej w Wojsku Polskim II RP. Kolejność przedstawiania pułków wyznaczał ich numer, ale zasadę tę zmieniano, gdy któraś z jednostek była odznaczona Orderem Wojennym Virtuti Militari ${ }^{25}$. Zgodnie z tym, na odznace kolejność barw pułków powinna być inna. Na miejscu pierwszym winien znaleźć się 14. puł Jazłowieckich, kawaler Orderu Virtuti Militari z roku 1920, odznaczony też za niezwykłe męstwo w kampanii 1939 roku w Polsce, na miejscu drugim 9. puł Małopolskich, odznaczony Orderem Virtuti Militari za kampanię 1939 roku, na trzecim 6. puł Kaniowskich i 6. dak na czwartym ${ }^{26}$.

Stargardzka 6. BKPanc szkoliła się intensywnie, brała udział w wielu ćwiczeniach i operacjach prowadzonych w kraju i za granicą, m.in. w Iraku w 2003 roku. Tym bardziej niespodziewana była decyzja ministra ON o rozwiązaniu jednostki, co nastąpiło 30 czerwca 2007 roku $^{27}$. Nie zlikwidowano jednego batalionu, który wszedł w skład 12. Brygady Zmechanizowanej im. gen. broni Józefa Hallera jako 2. Batalion Piechoty Zmotoryzowanej (bpzmot). Przejął on dziedzictwo tradycji, barwy i symbolikę 14. Pułku Ułanów Jazłowieckich oraz otrzymał nazwę wyróżniającą, 14. Batalion Ułanów Jazłowieckich”28. W ten sposób zachowano ważne dziedzictwo, święto batalionu przypada 11 lipca, w rocznicę bitwy pod Jazłowcem. Ten pododdział posiada własną odznakę o wymiarach 55 x $55 \mathrm{~mm}$, nawiązującą bezpośrednio do kształtu znaku poprzedników, w której datę „1918” zamieniono na „1994”. Wybito ją w poznańskiej pracowni grawerskiej Jarosława Jakubowskiego. Żołnierzy batalionu wyróżniają też żółte proporczyki z białym paskiem noszone na beretach oraz oznaki brygady z liczbą „12” na rękawach kurtek mundurów wyjściowych i polowych ${ }^{29}$.

25 Podobna zasada panowała wśród żołnierzy o tym samym stopniu - pierwszeństwo miał zawsze kawaler Orderu „Virtuti Militari”.

${ }^{26}$ Tym, Dzieje ułanów, 492; Kukawski, Ułani Jazłowieccy, 38.

27 Obiekty po 6. BKPanc zostały przejęte przez 12. Brygadę Zmechanizowaną i Brygadę Wsparcia Dowodzenia Dowództwa Wielonarodowego Korpusu Północny-Wschód.

28 Przekazanie tradycji nastąpiło na podstawie Decyzji Ministra Obrony Narodowej nr 349/ MON z 3 sierpnia 2007 r. w sprawie przejęcia dziedzictwa tradycji oraz nazwy wyróżniającej przez pododdziały 12. Brygady Zmechanizowanej im. gen. broni Józefa Hallera w Szczecinie.

29 Sprawę tę regulowało zarządzenie Ministra Obrony Narodowej z dnia 21 maja 1996 roku (Nr 28/MON: w sprawie odznak pamiątkowych i odznak absolwentów oraz oznak dla celów rozpoznawczych w Siłach Zbrojnych Rzeczypospolitej Polskiej). Po raz pierwszy w beretach przyozdobionych żółtymi proporczykami z białym paskiem nawiązującymi do barw 14. puł Jazłowieckich wystąpili żołnierze 1. bcz 6. BKPanc w dniach 30 i 31 sierpnia 1996 roku w Stargardzie 
Kanclerz Kapituły Orderu Wojennego Virtuti Militari gen. bryg. w st. spocz. Stanisław Nałęcz-Komornicki w 1999 roku podjął rozmowy z przedstawicielami Rodziny Jazłowieckiej w sprawie utożsamienia 1. Batalionu Czołgów im. 14. Pułku Ulanów Jazłowieckich z poprzednikiem. Miało to nastąpić w drodze przeniesienia Krzyża Srebrnego Orderu Wojennego Virtuti Militari z historycznego sztandaru pułku na proporzec batalionu, ale sprzeciwiło się temu londyńskie Koło Pułkowe 14. Pułku Ułanów Jazłowieckich. Dopiero po jego rozwiązaniu się i po uzyskaniu zgody wszystkich żyjących weteranów pułku, nastąpiło utożsamienie stargardzkiego 14. batalionu Ułanów Jazłowieckich z 14. Pułkiem Ułanów Jazłowieckich. Doszło do tego 9 stycznia 2008 roku, w trakcie uroczystego pożegnania sformowanej na bazie 12. Brygady Zmechanizowanej X zmiany Polskiego Kontyngentu Wojskowego w Iraku, której rdzeń stanowił 14. batalion Ułanów Jazłowieckich. Order Wojenny Virtuti Militari na sztandar pododdziału przeniósł kanclerz Kapituły Orderu Wojennego Virtuti Militari gen. bryg. w st. spocz. Stanisław Nałęcz-Komornicki. Tym samym dokonał się ostatni akt procesu przekazania bojowych dokonań sławnych poprzedników następcom ze Stargardu.

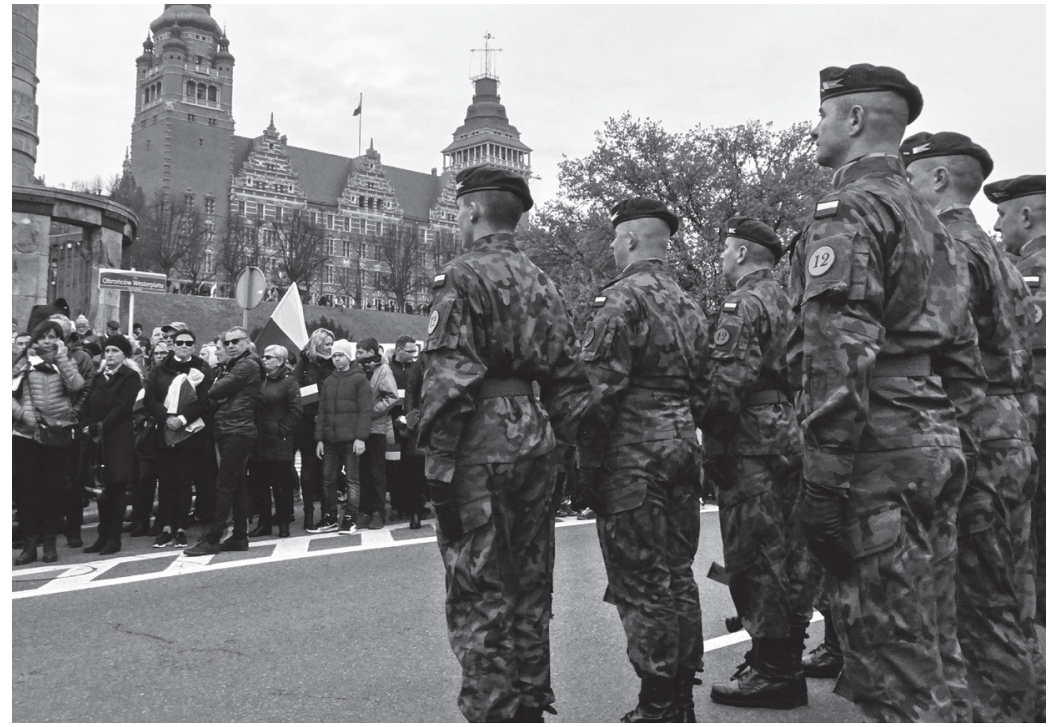

Rycina 2. Żołnierze 2. bpzmot Ułanów Jazłowieckich 12. BZ podczas obchodów święta 100 rocznicy nieodległości. Zwracają uwagę proporczyki na beretach i oznaki 12. BZ na rękawach. Szczecin, Wały Chrobrego 11 listopada 2018 roku (fot. Grzegorz Ciechanowski)

Szczecińskim podczas uroczystości przejęcia tradycji i wręczenia nowego sztandaru. Zob. Kukawski, Utani Jazłowieccy, 38. 


\section{Stargardzka tradycja Szwoleżerów Rokitniańskich}

Drugą grupą jednostek, które przyjmowały kawaleryjskie tradycje były bataliony rozpoznawcze wchodzące organicznie w skład dywizji wojsk lądowych. Był to zabieg dość kontrowersyjny z wcześniej wspomnianych powodów - weterani kawaleryjskich pułków niechętnie podchodzili do projektu powierzenia dziedzictwa swoich jednostek formacjom o niższym statusie organizacyjnym. Jednym z nich był 2. Batalion Rozpoznawczy 2. Dywizji Zmechanizowanej ${ }^{30}$.

Jak wspomina jego ówczesny dowódca ppłk Marek Gajewski, idea ubiegania się o przejęcie tradycji 2. Pułku Szwoleżerów Rokitniańskich narodziła się w jednostce, ten pomysł nie został ,narzucony z Warszawy”. O wyborze decydował co oczywiste numer, ale dochodził do tego niezwykły zbieg okoliczności w okresie międzywojennym szwoleżerowie stacjonowali w Starogardzie na Pomorzu, a zainteresowani przejęciem tradycji - w Stargardzie Szczecińskim. Taka analogia nazw miejscowości działała na emocje obu stron. Nie mając kontaktu z weteranami sławnej jednostki, dowództwo 2. brozp wystosowało pismo do burmistrza Stargardu ${ }^{31}$. Adres okazał się trafiony, władze miasta współpracowały z miejscowym Muzeum Ziemi Kociewskiej, a ta placówka utrzymywała kontakt z przedwojennymi szwoleżerami, którzy w Starogardzie Gdańskim nie posiadali swojego stowarzyszenia ${ }^{32}$.

2. Pułk Szwoleżerów Rokitniańskich swój rodowód wywodził z formacji kawalerii Legionów Polskich tworzonych od początku I wojny światowej na ziemiach zaboru austriacko-węgierskiego. Wzięły one udział w kampanii karpacko-bukowińskiej, a do historii polskiego oręża przeszła szarża z 13 czerwca 1915 roku na pozycje piechoty rosyjskiej pod wsią Rokitna, kiedy na wraże okopy ruszyli ułani 2. szwadronu II Brygady Legionów Polskich prowadzeni przez rtm.

30 Tadeusz Krząstek, Andrzej Czesław Żak, Z ziemi włoskiej do Polski (Warszawa: Ministerstwo Obrony Narodowej, 1997), 87. W 1989 roku 20. Warszawska Dywizja Pancerna została zrestrukturyzowana, przyjęła też numer i tradycje rozformowywanej 2. Warszawskiej Dywizji Zmechanizowanej z Nysy. Zob. Grzegorz Ciechanowski, „Tradycje wojskowe związków taktycznych wojsk lądowych na Pomorzu Zachodnim", w: Pomorze Militarne. Stulecie odrodzenia Polski a region, red. Kazimierz Kozłowski (Szczecin: Kadruk, 2018), 150.

${ }^{31}$ Relacja płk. Marka Gajewskiego, dowódcy 2. brozp Szwoleżerów Rokitniańskich z dnia 25.02.2019 roku.

32 W 1950 do nazwy Starogard dodano przymiotnik „Gdański”, w celu odróżnienia go od Stargardu Szczecińskiego. 
Zbigniewa Dunin-Wąsowicza ${ }^{33}$. Okupili to krwawymi stratami, poległ m.in. dowódca szwadronu, z atakujących 64 ułanów wróciło sześciu, a efekty ataku nie zostały wykorzystane, bo własna piechota $\mathrm{w}$ niedostatecznym stopniu wsparła ułanów. Tym niemniej czyn ten stał się symbolem niezwykłego poświęcenia polskich kawalerzystów ${ }^{34}$. Zasłużona w bojach legionowych formacja otrzymała 1 stycznia 1919 roku „gwardyjskie” miano 2. Pułku Szwoleżerów ${ }^{35}$, a pół roku później 20 czerwca, dla upamiętnienia tej szarży, otrzymała nazwę 2. Pułku Szwoleżerów Rokitniańskich ${ }^{36}$. W styczniu 1920 roku pułk uczestniczył w przejmowaniu Pomorza z rąk niemieckich, od kwietnia walczył w Galicji Wschodniej przeciwko oddziałom 1. Armii Konnej, a swój szlak bojowy zakończył 10 października 1920 roku udziałem w zdobyciu Korostenia.

2. Pułk Szwoleżerów Rokitniańskich we wrześniu 1939 roku w składzie Pomorskiej BK toczył boje okupione wielkimi stratami z przeważającymi siłami niemieckimi w Borach Tucholskich, walczył na linii Wisły o utrzymanie przepraw mostowych, uczestniczył w bitwie nad Bzurą, przebijał się do Warszawy, a żołnierze którym to się udało, wzięli udział w jej obronie ${ }^{37}$.

Pierwsze spotkanie z gośćmi ze Starogardu Gdańskiego odbyło się w stargardzkich „czerwonych koszarach” 1 kwietnia 1995 roku. Wzięli w nim udział, obok dowództwa batalionu, dyrektor Muzeum Ziemi Kociewskiej Andrzej Błażyński oraz dwaj szwoleżerowie por. J. Leszczyński i J. Czapiewski ${ }^{38}$. W kronice starogardzkiego muzeum zapisano:

Celem spotkania było przedstawienie propozycji przejęcia tradycji 2 pSzR przez w/w jednostkę [2. brozp - przyp. aut.], uzyskanie opinii o tym b. szwoleżerów, omówieniu trybu przygotowań i etapów postępowania celem zmiany nazwy dla

${ }^{33} \mathrm{~W}$ pierwszych dniach czerwca 1915 roku 2. i 3. szwadron zostały połączone w II dywizjon, który wchodził w skład II Brygady Legionów Polskich. Autor posługuje się oryginalną numeracją jednostek stosowaną w danym okresie.

${ }^{34}$ Wiesław Gogan, 2. Pułk Szwoleżerów Rokitniańskich (Pelplin: Wydawnictwo Bernardinum, 2015), 42-58.

${ }^{35}$ Wyróżnienie taką nazwą było nawiązaniem do chwały 1. Pułku Lekkokonnego Polskiego Gwardii Cesarskiej (fr. ler régiment de chevau-légers lanciers polonais de la Garde impériale), istniejącego w latach 1807-1815, wsławionego m.in. szarżą 3. szwadronu tego pułku pod Somosierrą.

${ }^{36}$ Gogan, 2. Putk, 107-111.

37 Mariusz Kardas, „Jak to Gdynia kawalerią stała: tradycje kawaleryjskie przedwojennej Gdyni”, Zeszyty Gdyńskie 4 (2009): 163.

${ }^{38}$ Kronika Muzeum Ziemi Kociewskiej w Starogardzie, Muzeum Ziemi Kociewskiej w Starogardzie, bzs. 
Batalionu. Ustalono, że Muzeum będzie wspomagać te poczynania swoją wiedzą oraz eksponatami ${ }^{39}$.

W efekcie 13 kwietnia 1996 roku na rynku w Stargardzie Szczecińskim odbyła się uroczystość wręczenia sztandaru 2. Batalionowi Rozpoznawczemu Szwoleżerów Rokitniańskich, bo taką oficjalną nazwę otrzymała wówczas jednostka ${ }^{40}$. Batalion swoje doroczne święto obchodził 13 czerwca na pamiątkę szarży pod Rokitną. Jak wspomina dowódca batalionu ppłk Marek Gajewski, jego podwładni pozytywnie odnieśli się do idei przejęcia tradycji sławnego pułku ze Starogardu. Świadczy o tym również kształt odznaki nawiązujący bezpośrednio do przedwojennego wzoru zaprojektowanego w roku 1921 przez rtm. Stanisława Lewickiego. Kolejny, niewiele różniący się projekt został zatwierdzony w roku 1926. Była to dwuczęściowa odznaka, mająca kształt krzyża pokrytego biała emalią o ramionach zwężających się ku środkowi i zamkniętych wklęsłą krawędzią z kulkami. Na przecięciu jego ramion umieszczono dwie skrzyżowane lance z proporczykami w barwach pułku - białe z amarantowym paskiem. Na środku znalazł się wizerunek rogatej czapki szwoleżerskiej z okresu Księstwa Warszawskiego $^{41}$.

W pierwszym wzorze z 1921 roku na lewym ramieniu krzyża umieszczona została data „1914”, na górnym „1915”, na prawym „1918”, na dolnym znalazły się inicjały pułku ,2SzR”. Na odznace z 1926 roku pozostały tylko inicjały. W batalionie rozpoznawczym 2. DZ zaadoptowano ten wzór, wzór odznaki opracowany przez kpt. Piotra Skwarka miał nieco mniejsze rozmiary 39 x 39 mm, usunięto też wspomniane inicjały. Pierwsze egzemplarze tego wzoru wykonał warszawski grawer Andrzej Panasiuk ${ }^{42}$.

39 Tamże.

40 Decyzja Nr 23/MON Ministra Obrony Narodowej z dnia 20 marca 1996 r. w sprawie przejęcia dziedzictwa tradycji, nadania nazwy wyróżniającej oraz ustanowienia dorocznego Święta 2. Batalionu Rozpoznawczego 2. Pomorskiej Dywizji Zmechanizowanej im. gen. Jana Henryka Dąbrowskiego w Stargardzie Szczecińskim.

${ }^{41}$ Więcej na temat odznaki pułkowej: Filipow, Odznaki, 10-11; Wielecki, Sieradzki, Wojsko Polskie, 88-89; Juliusz S. Tym, Wielka Księga Kawalerii Polskiej. Odznaki Kawalerii. 2 Pułk Szwoleżerów. Odznaka pułkowa (Warszawa: Edipresse, 2019), 5-10.

42 Sawicki, Wielechowski, Odznaki Wojska Polskiego 1918-1945, 109. Autorzy tej publikacji informują, że odznaka została wypuszczona w wersji kolekcjonerskiej. W rzeczywistości przygotowano regulamin jej nadania, jej wizerunek widnieje na zaproszeniu rozsyłanym do gości uroczystości wręczenia sztandaru, choć pierwsze egzemplarze wręczono nieco później. Relacja płk. Marka Gajewskiego, dowódcy 2. brozp Szwoleżerów Rokitniańskich z dnia 25.02.2019 roku. 

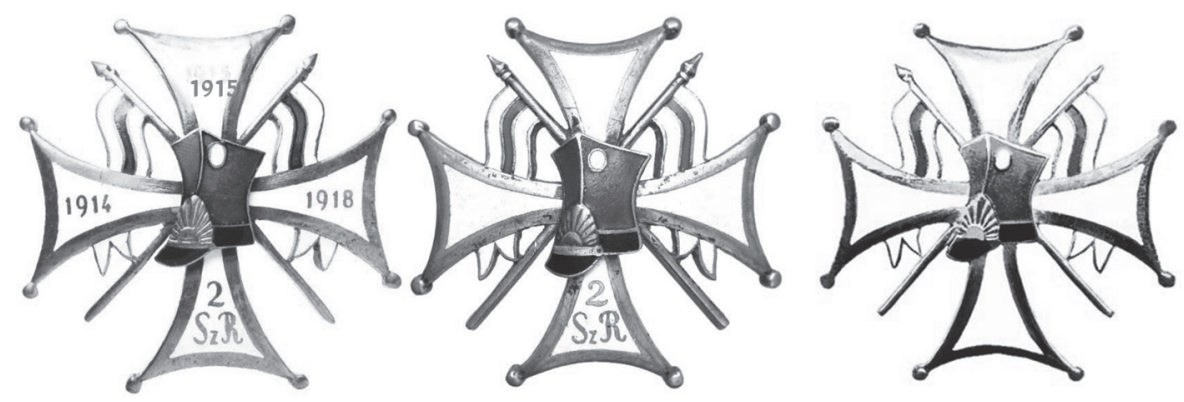

Rycina 3. Odznaki szwoleżerów: od lewej 2. pSzR pierwszego wzoru,

2. pSzR drugiego wzoru i 2. br Szwoleżerów Rokitniańskich (opracowanie własne)

Szwoleżerskie tradycje w Stargardzie Szczecińskim nie funkcjonowały jednak długo. Dwa lata później rozwiązano 2. Pomorską Dywizję Zmechanizowaną i większość jednostek wchodzących w jej skład, w tym 2. Batalion Rozpoznawczy Szwoleżerów Rokitniańskich. Tradycji tej jednostki nie przekazano żadnej innej formacji Wojska Polskiego. Coś jednak pozostało, choć w symbolicznym wymiarze. Rysunek odznaki 2. pSzR prezentowany jest dziś w sali tradycji 7. Pomorskiej BOW w Słupsku, która dziedziczy tradycje Pomorskiej Brygady Kawalerii, w skład której wchodził starogardzki pułk.

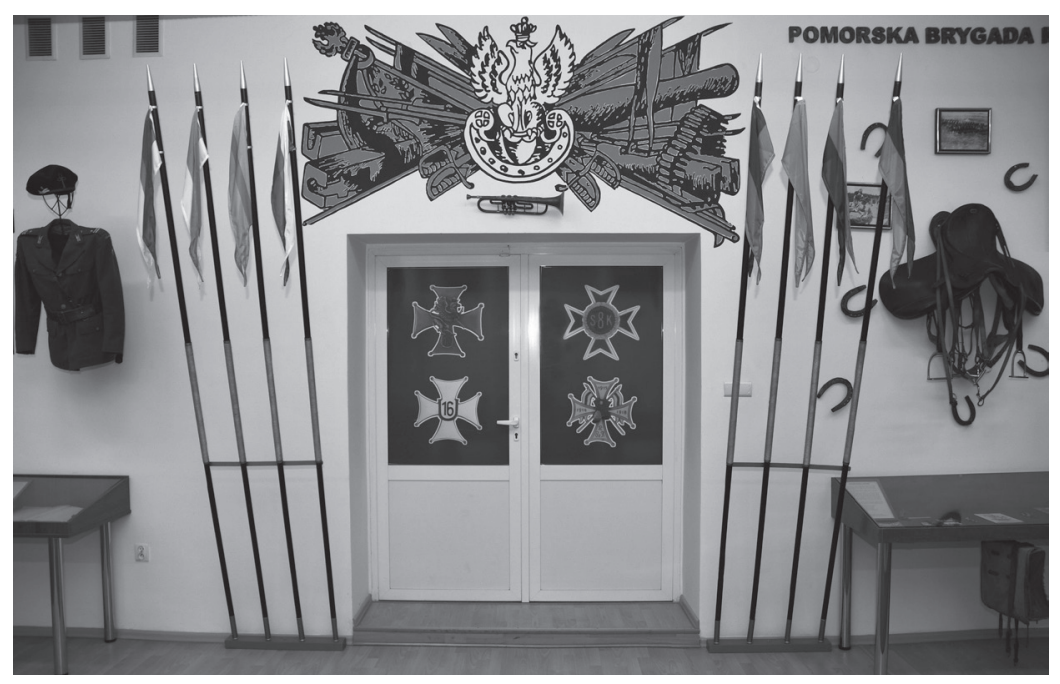

Rycina 4. Imitacje lanc z proporczykami i odznaki pułków Pomorskiej BK, wśród nich symbole

2. Pułku Szwoleżerów Rokitniańskich, ostatnie ,żywe” elementy odwołujące się do tradycji tej jednostki. Słupsk, 2019 rok (fot. Marcin Lasoń) 
Na tym jednak historia kultywowania tradycji 2. pSzR się nie kończy. W 2006 roku w Starogardzie Gdańskim powstało Stowarzyszenie Szwadron Kawalerii im. 2 Pułku Szwoleżerów Rokitniańskich, któremu Zrzeszenie Kół Pułkowych Kawalerii w Londynie przyznało prawo do dziedziczenia tradycji bojowej i barw tej elitarnej jednostki. Wchodząc w skład Federacji Kawalerii Ochotniczej Rzeczypospolitej Polskiej, szwadron otrzymał zgodę na używanie mundurów, nazewnictwa i stopni kawaleryjskich zaakceptowanych przez Ministerstwo Obrony Narodowej. Członkowie stowarzyszenia w historycznych mundurach uczestniczą w obchodach świąt państwowych i wojskowych, współpracując głównie z dowództwem i jednostkami 16. Pomorskiej Dywizji Zmechanizowanej im. Króla Kazimierza Jagiellończyka ${ }^{43}$. Dowództwo tego związku taktycznego zlokalizowane jest w Elblągu, jednostki dywizji stacjonują na Warmii i Mazurach.

\section{AbstrakT}

Po 1990 roku w Siłach Zbrojnych RP rozpoczął się proces dziedziczenia tradycji wojskowych, po 45-letniej przerwie okresu PRLu, obejmujących tysiącletnią orężną historię Polski. Przebiegał on oddolnie, przy dużym zaangażowaniu żołnierzy zawodowych poszczególnych jednostek, wspierany był przez działania wyspecjalizowanych instytucji Ministerstwa Obrony Narodowej, co wiązało się m.in. z przekonaniem do tej idei stowarzyszeń weteranów czy członków rodzin dowódców, którzy mieli stać się patronami określonych formacji. Starano się o przyznanie dziedzictwa formacji o tym samym numerze oraz profilu służby. W wojsku od 1946 roku nie istniały jednostki kawalerii, stąd w resorcie obrony podjęto działania, aby określone pułki zmechanizowane, później brygady oraz dywizyjne bataliony rozpoznawcze przejęły tradycje tego rodzaju wojsk, tak zasłużonego w historii polskiej wojskowości.

Na mapie Pomorza Zachodniego szczególne miejsce zajmował wówczas garnizon w Stargardzie Szczecińskim, gdzie stacjonowały jednostki wchodzące w skład dwóch różnych dywizji zmechanizowanych (DZ). W artykule opisano proces dziedziczenia tradycji przez 6. Brygadę Kawalerii Pancernej 12. DZ oraz 2. Batalion Rozpoznawczy 2. DZ z uwzględnieniem analizy falerystycznej.

43 Szwadron Kawalerii im. 2 Pułku Szwoleżerów Rokitniańskich, dostęp 17.01.2019, http:// www.2szwol.darsite.pl. 


\title{
CAVALRY COLOURS AND TRADITIONS OF CONTEMPORARY ARMY UNITS OF THE STARGaRd GaRRISON
}

\begin{abstract}
After the year 1990 in the Polish Armed Forces started the process of inheritance of the military traditions encompassing thousand years old history of the Polish Army. It was a grassroots process with great commitment from the military professionals in the army units, supported by the action of the specialized institutions of the Ministry of National Defence aimed at persuading this idea to the veteran associations or family members of the commanders, who were to become patrons of particular army formations. Efforts were made to assign the heritage to the formation of the same number and service profile. From 1946 in the Army didn't exist the cavalry units, therefore the Department of Defence took actions so as to particular motorized regiments, later brigades and divisional reconnaissance battalions, assumed the traditions of this branch of service, so merited in the history of the Polish military. On the map of Western Pomerania particular position occupied at that time the garrison in Stargard Szczeciński, where were stationed units belonging to two different mechanized divisions. The article describes the process of tradition inheritance by the 6th Armoured Cavalry Brigade of the 12th Mechanized Division and the 2nd Reconnaissance Battalion of the 2nd Mechanized Division, with addition of the phaleristic analysis.
\end{abstract}

\section{Bibliografia}

Źródła

Decyzja Nr 23/MON Ministra Obrony Narodowej z dnia 20 marca 1996 r. w sprawie przejęcia dziedzictwa tradycji, nadania nazwy wyróżniajacej oraz ustanowienia dorocznego Święta 2. Batalionu Rozpoznawczego 2. Pomorskiej Dywizji Zmechanizowanej im. gen. Jana Henryka Dąbrowskiego w Stargardzie Szczecińskim.

Kronika 1. Batalionu Czołgów 6. Brygady Kawalerii Pancernej. Sala Tradycji 12. Brygady Zmechanizowanej w Stargardzie.

Kronika Muzeum Ziemi Kociewskiej w Starogardzie. Muzeum Ziemi Kociewskiej w Starogardzie.

Rozkaz Dowódcy 6. Brygady Kawalerii Pancernej nr 103 z dn. 30.08.1996 w sprawie przekazania tradycji dla pododdziałów 6. Brygady Kawalerii Pancernej.

Materiały niepublikowane

Radziwiłłowicz, Dariusz. Tradycje i symbole współczesnych jednostek WP na Warmii i Mazurach, maszynopis. 


\section{Relacje}

Relacja płk. Marka Gajewskiego, dowódcy 2. brozp Szwoleżerów Rokitniańskich z dnia 25.02.2019 roku.

Opracowania

Ciechanowski, Grzegorz „Tradycje wojskowe związków taktycznych wojsk lądowych na Pomorzu Zachodnim". W: Pomorze Militarne. Stulecie odrodzenia Polski a region, red. Kazimierz Kozłowski. Szczecin: Kadruk, 2018.

Dembiniok, Józef, Bernard Szczech, Andrzej Urbański. Oznaki i odznaki Polskich Sił Zbrojnych na Zachodzie. Część I, Wojsko Polskie we Francji I Korpus Polski w Wielkiej Brytanii. Warszawa: KAW, 1984.

Filipow, Krzysztof. Odznaki pamiatkowe Wojska Polskiego 1921-1939. Kawaleria. Warszawa: Feniks, 1992.

Gogan, Wiesław. 2 Pułk Szwoleżerów Rokitniańskich. Pelplin: Wydawnictwo Bernardinum, 2015.

Krząstek, Tadeusz, Andrzej Czesław Żak. Z ziemi włoskiej do Polski. Warszawa: Ministerstwo Obrony Narodowej, 1997.

Kukawski, Lesław. Ułani Jazłowieccy. Barwa i broń 1918-1998. Grajewo: Eko-Dom, 2001 .

Mijakowski, Krzysztof, red. 14. Pułk Ułanów Jazłowieckich. Wielka Księga Kawalerii Polskiej 1918-1939. Warszawa: Edipresse Polska, 2012.

Partyka, Jan. Odznaki i oznaki Polskich Sit Zbrojnych na Zachodzie 1939-1945 (wojska lądowe). Rzeszów: Libri Ressovienses, 1997.

Sawicki, Zdzisław, Adam Wielechowski. Odznaki Wojska Polskiego 1918-1945. Katalog Zbioru Falerystycznego: Wojsko Polskie 1918-1939: Polskie Sity Zbrojne na Zachodzie. Warszawa: Pantera Books, 2007.

Sawicki, Zdzisław, Adam Wielechowski. Odznaki Wojska Polskiego 1989-2002. Katalog zbioru falerystycznego. Warszawa: Bellona, 2003.

Smoliński, Aleksander. „W sprawie przywracania tradycji we współczesnym Wojsku Polskim (sztandary, nazwy formacji, mundur)". W: IV Ogólnopolskie Forum Historyków Wojskowych. Koszalin 16 XII 1998, red. Bogusław Polak. Koszalin: Politechnika Koszalińska, 1999.

Tym, Juliusz S., red. Dzieje ułanów jazłowieckich. Warszawa: IPN, 2019.

Tym, Juliusz S. Szarża pod Rokitna 13 czerwca 1915 roku. W: Wielka księga Kawalerii Polskiej. 2 Pułk Szwoleżerów, Warszawa: Edipresse, 2012.

Tym, Juliusz S. Wielka Księga Kawalerii Polskiej. Odznaki Kawalerii. 2 Pułk Szwoleżerów. Odznaka pułkowa. Warszawa: Edipresse, 2019.

Wielecki, Henryk, Rudolf Sieradzki. Wojsko Polskie 1921-1939: organizacja i odznaki kawalerii. Warszawa: Crear, 1992.

Znamierowski, Alfred. Heraldyka i weksylologia. Warszawa: Arkady, 2017. 
Artykuły

Filipow, Krzysztof. „Rozwój badań nad falerystyka w Polsce. Stan i perspektywy”. Kwartalnik Historii Nauki i Techniki 37 (1985), 2: 357-370.

Kardas, Mariusz. „Jak to Gdynia kawalerią stała: tradycje kawaleryjskie przedwojennej Gdyni”. Zeszyty Gdyńskie 4 (2009), 151-169.

Netografia

Goździk, Krzysztof. Znak Pułkowy 14 Pułku Ułanów Jazłowieckich. Dostęp 14.01.2019. https://dobroni.pl.

Kultywowanie tradycji oręża polskiego w Wojsku Polskim. Dostęp 27.12.2018. https:// tradycje.wp.mil.pl.

Rodzina 14 Pułku Ułanów Jazłowieckich. Dostęp 15.01.2019. http://www.ulanijazlowieccy.pl.

Szwadron Kawalerii im. 2 Pułku Szwoleżerów Rokitniańskich. Dostęp 12.01.2019. http:// www.2szwol.darsite.pl. 